\title{
FEDERALISM AND WATER RESOURCES DEVELOPMENT
}

\author{
ERNEST A. ENGELbERT*
}

No aspect of federalism is currently being subjected to more intensive public inquiry and appraisal than the intergovernmental relationships of water resources development. The rights and responsibilities of the federal government vis-à-vis the states in this area have become a subject of increasing political and administrative controversy ever since World War II. The warm debates over Hell's Canyon, Dinosaur National Monument, and the Dixon-Yates contract in the recent presidential campaign remind us how prominently matters of this kind have become major issues of public policy. Similarly, a review of federal and state-sponsored studies within the last decade shows that there have been more major investigations of various phases of water resources than of any other domestic function. ${ }^{1}$

To a great degree, recent public interest in this area stems from the major demands that a growing economy, a rising standard of living, and an intensified national defense have placed upon the nation's water resources. Ever-widening concern with the organization and operation of water resources programs, however, must also be associated with the re-evaluation of our federal system of government which is currently taking place. ${ }^{2}$ The centralizing influences of technology and communications and two decades of unprecedented national government growth during depression and war are forcing a sober reappraisal of the role of the states and local governments in our national system.

In no other arena are the complex aspects of federalism so starkly presented as in water resources. Their development epitomizes, perhaps better than any other function, the need for intergovernmental cooperation. Moreover, there are few functions in which programs for improvement can so quickly produce changes in the physical and social environment and in the character of government. Whether we turn to

- A.B. 1939, University of Wisconsin; M.P.A. I949, Ph.D. 1950, Harvard University. Associate Professor of Political Science, University of California at Los Angeles. Formerly Legislative Planning Analyst, United States Department of Agriculture; Senior Organization Analyst, Task Force on Natural Resources of the United States Commission on Organization of the Executive Branch of the Government; consultant to various public and private agencies on resources problems, including the California Legislature, the Pacific Southwest Federal Inter-Agency Technical Committee, and the Ford Foundation. Author of several publications in the field of government and resources.

${ }^{1}$ From evidence assembled from materials furnished by the Council of State Governments and from checklists of governmental reorganization studies. During 1955-56, for example, thirty-one states were undertaking water studies of varying scope. See Council of State Governments, THE Book of the States, 1956-1957, at 376 (1956).

'Some noteworthy examples are Coma'n on Intergovernmental Relations, Report to the President (1955); Arthur W. Macmahon (Ed.), Federalism Mature and Emergent (1955); William Anderson, The Nation and the States, Rivals or Partners (1955); Leonaro D. White, The States AND THE NATION (1953). 
the wording of the latest political party platforms or to more scholarly studies, the significance of water resources development for our political system of federalism is greatly evident.

It would be an exaggeration to say that our federal system has now reached the political crossroads with respect to water resources programs and that no further large-scale development will occur until present federal-state controversies are resolved. The imperatives of water needs for a growing national economy will inevitably push developments forward, whether or not the political logic and institutions have been sufficiently formulated to guide the courses of action. But it is also significant that, as a nation, we are currently doing much soul-searching to find suitable alternatives to undue control and domination of resources developments by the federal government on the one hand, or to the weak and inadequate programs of the states on the other. We are less confident about solutions for this problem then we were in the r93o's. Today, fewer writings are found to the effect that the states are outmoded as agencies for water resources development or that the nation's salvation rests in more Tennessee Valley Authorities. Instead, the need for devising water resources programs that will strengthen the over-all political structure is recognized.

Within this setting, it is the object of this paper (I) to review briefly the relative positions of the federal government and the states for water resources development; (2) to evaluate some of the intergovernmental relationships in this field; and (3) to explore some courses of action which would strengthen, in particular, the role of the states.

\section{I}

\section{The Status of Federal and State Developments}

\section{A. Legal Powers}

As in so many other fields of public activity, the legal powers of both the federal government and the states for water resources development are still evolving. Although the Federal Constitution does not specifically mention water resources, legislation and court decisions have demarcated primary federal and state responsibilities; but a vast legal no-man's-land still exists, particularly with respect to water rights. Currently, there are a number of judicial cases in western states wending their way to the nation's highest court, the decisions of which will have far-reaching impact upon the future course of water resources development. ${ }^{3}$

The federal government's authority over water resources stems from several basic powers granted by the Constitution, notably its powers over commerce on navigable streams, its proprietary powers over its own lands and property, and its

\footnotetext{
${ }^{3}$ Most notable of cases on appeal to the United States Supreme Court is one in which the California Supreme Court, by a 4 to 3 decision, invalidated the federal 160 -acre limitation in its application to private lands. Ivanhoe Irr. Dist. v. All Parties, 47 Cal.2d 603, 306 P.2d 824 (1957). This decision overturns a federal policy established in the passage of the Reclamation Act of 1902, 32 STAT. 388, and, if permitted to stand, could materially alter the Burcau of Reclamation's program in western states.
} 
powers to appropriate funds to provide for the nation's general welfare. In addition, the federal government, on occasion, has been able to exercise certain jurisdiction over streams on the basis of its war and treaty-making powers, the former being an important legal justification for the early Tennessee Valley development. ${ }^{5}$ Upon these powers have been built the federal government's authority to improve navigation on navigable streams as well as nonnavigable tributaries, to carry out measures for flood control, to undertake irrigation and reclamation programs, to develop and dispose of hydroelectric power, to determine the use of water on the public domain, and to engage in large-scale river basin developments which are in the general interest. Corollary to these functions, the federal government is empowered to engage in fish and wildlife protection, recreational programs, pollution control, and related functions. In general, the federal government has been moving toward larger multiple-purpose projects. ${ }^{6}$

Despite what appears to be very extensive federal powers over water resources, however, the states are not without their own important spheres of jurisdiction, although these have not always been vigorously prosecuted. Perhaps most important is a state's authority, under its police power, to regulate various water activities for the general welfare, such as the production of water for domestic purposes or the control of sewage disposal. This, of course, includes the right to regulate industries engaged in different aspects of water use and development where these are not in conflict with regulations derived from federal powers. Of almost equal prominence is a state's power to determine the allocation and distribution of both surface and underground waters within the state. The states are permitted to adopt whatever system of water law they choose, including the law for those lands which have passed from the federal government to the states, provided it does not conflict with the federal government's powers over navigation.7 Finally, the states possess powers to engage in interstate action with respect to water use and development. Agreements reached via interstate compacts are valid, even though these may conflict with existing state law. ${ }^{8}$

At the risk of gross oversimplification, it can be said that, on the whole, the federal government's powers have been used to guide and control the development of major streams in the country, whereas the states have had greater responsibility for the distribution and use of waters locally. In the past, most of the constitutional questions have involved either the litigation of water rights or the demarcation of federal and state spheres of authority. More recently, however, in keeping with

\footnotetext{
- The most comprehensive treatise on the constitutional aspects of water resources development is 3 Prestident's Water Resources Policy Comm'n, Report (1950), entitled Water Resources Law.

${ }^{5}$ Ashwander v. Tennessec Valley Authority, 297 U.S. 288 (1936).

- See 3 Prestdent's Water Resources Policy Comm'n, op. cit. supta note 4, at 312.

7 To remove any question concerning water rights in states created out of federal territory, the Desert Land Act of 1877 , I9 STAT. 377, as amended, 43 U.S.C. $\$ 321$ (1952), in effect provided that all nonnavigable waters on these lands should be reserved for public use under state law.

${ }^{8}$ Hinderlider v. La Plata River and Cherry Creek Ditch Co., 304 U.S. 92 (1938).
} 
the growth of public administration, more cases have turned upon the powers of administrative agencies and the conduct of programs.

It is not unlikely, as both levels of government broaden and intensify their programs for water resources, that constitutional and legal conflicts will increase. At the moment, there is considerable agitation in western states for a review of federal-state legal relationships, and recently, a number of national organizations jointly sponsored a recommendation stating that "legislation is urgent to clarify the relative authority of the states and the federal government in the disposition of water." Many groups have found that the exploitation of legal issues is the best cover for an attack upon objectionable policies. It will take nothing less than a wise development of federalistic arrangements to keep these conflicts to a minimum.

\section{B. Evolution of Programs}

Within the legal framework, the evolution of federal and state programs for water resources have been conditioned by many of the same broad political and economic considerations which have influenced the development of other governmental functions. However, two unrelated factors, namely navigation and catastrophe, have been particularly significant for determining the unfolding of federal-state relationships. The importance of American waterways in opening the continent and civilizing the frontier gave the federal government, with its power over navigation, some strategic advantages in the development of this activity which it did not possess with respect to some other domestic functions. Similarly, the necessity for developing adequate protection against flood and drought disaster brought about a certain measure of intergovernmental cooperation at a far earlier stage in American history than might otherwise have been the case.

A number of distinguishing features can be noted in the historical development of federal-state water resources activities. Outstanding is the fact that both the federal and state governments have given leadership to phases of water development at various periods. ${ }^{10}$ For example, during the so-called canal-building era of the nineteenth century, the states were in the forefront in improving navigation of waterways; and a little later, along the banks of the Ohio and Mississippi Rivers, they were taking the initiative in flood control. During the latter half of the nineteenth century, however, after state debacles and mismanagements in canal building and levee construction, the federal government took the helm and has continued to be in the forefront of this activity. In other fields, such as the regulation of hydroelectric power development, the states also took the first steps toward control, but with the advent of federal intervention into this field under the Federal Power Act of

\footnotetext{
${ }^{-}$Second Inter-Organization Conference on Water Law, St. Louis, Jan. 24-25, 1956. Organizations represented at this conference were: American Farm Bureau Federation, Chamber of Commerce of the United States, Engineers Joint Council, Mississippi Valley Association, National Reclamation Association, National Rivers and Harbors Conference, and National Water Conservation Confercnce.

${ }^{10}$ For a historical summary of the states' role in water resources development, see Cliprono J. Hrnning, State Conseryation of Resources (1939); sce also Lepawsky, Water Resources and American Federalism, 44 Ax. PoL. Scr. Rev. 631 (r950).
} 
$1920{ }^{11}$ state and federal responsibilities have developed somewhat simultaneously, particularly in the more progressive states. For still other water resources activities, such as the provision of urban water supplies, the states have had virtually exclusive sway. Viewed in perspective, the state and local governments were the most influential in determining the course of water resources development during the nineteenth century, ${ }^{12}$ but beginning with the administration of Theodore Roosevelt, the federal government has gradually moved to the forefront to the point where it is the dominating force, at least on all of the country's major streams.

Another distinguishing aspect of water resources development in this country is that, at both the federal and state levels, water resources were initially developed for a single purpose and not on a related basis. Thus, the functions of navigation and flood control first received attention. Some protection of fish and wildlife was inaugurated by the states shortly after the Civil War, and toward the turn of the century, the first steps toward power regulation were taken. Also, during the 1880's, the western states became concerned with irrigation, rapidly followed by federal participation through the Carey Act of $1894 \cdot^{13}$ Among the functions which were unilaterally promoted after the turn of the century were pollution control, power generation, and recreational development.

The concept of multiple-purpose planning for water resources does not appear to have been publicly perceived until after rgoo, when flood control, power development, and irrigation began to be linked in development. ${ }^{14}$ However, it was not until after World War I that the federal government, with the enactment of the Federal Power Act in 1920 and the inauguration of the " 308 reports" in $1927,{ }^{15}$ adopted multiple-purpose water resources development as official public policy. ${ }^{16}$ Among the states, California was perhaps the first to think in terms of basin-wide development, when the legislature, in Ig2r, authorized the first studies leading to the adoption of the California Water Plan in r93r. ${ }^{\mathbf{1 7}}$

It is also noteworthy that much of the state development of water resources functions has come about through the initiative of local governments, with a minimum of state direction or support. This is particularly true for irrigation, drainage, and urban water supplies, where local districts underwrote the costs of much of the first development. Indeed, the state governments would not be as far advanced as they are

${ }^{11} 4$ I STAT. I063, I6 U.S.C. $\$ \$ 79$ I et seq. (1952).

${ }^{2.9}$ State expenditures for the improvement of inland navigation totaled more than $\$ 200$ million at the turn of the century, more than twice the expenditures of the federal government for this purpose up to that time. See Renne, State Conservation and Development of Natural Resources, State Government, June 1950, p. 134 .

${ }^{13} 28$ STAT. 422,43 U.S.C. $\$ 641$ (1952).

${ }^{2}$ Cross, $W . l$. McGee and the Idea of Conservation, 15 The Historian 748 (1953), states that it was the Inland Waterways Commission, created in 1907 , "which first put before a broad public the idea of multi-purpose river basin control. . .." For the evolution of this concept, see also Gifford Pinchor, Breaking New Ground (1947).

${ }^{15}$ See H.R. Doc. No. 308, 6gth Cong., Ist Sess. (I927).

${ }^{10}$ See 3 Prestdent's Water Resources Poltcy Comm'n, op. cit. supta note 4, at 406-io.

${ }^{17}$ Sce House Committee on Interior and Insular Affairs, Central Valley Projects Documents, H.R. Doc. No. $416,84^{\text {th }}$ Cong., 2 d Sess. 4-8 (1956). 
in some activities were it not for local enterprise. As it is, agencies of the federal government, notably the Bureau of Reclamation and the Corps of Engineers, now by-pass state agencies in many states in their dealings with local units. ${ }^{18}$

It is risky to attempt any assessment of how the federal government and the states now stand with respect to the development and control of various water functions. Not only do the states vary in their leadership in given fields, but there are considerable regional differences. As examples, Wisconsin has led in utility regulation; Montana has demonstrated considerable initiative in irrigation development; and California has fostered basin-wide planning. Yet, for the purpose of showing the relative importance of the two levels of government for specific functions, the following comparison can be made: The federal government now dominates in the fields of navigation, flood control, hydroelectric power development, irrigation, and river basin planning. The states dominate in the fields of water rights, urban water supplies, drainage, and fish and wildlife management. The responsibilities are more shared in the fields of power regulation, recreational planning, pollution control, and small watershed development. On federally-sponsored and financed projects, the federal government's influence is naturally greater. For the functions in which state and federal responsibilities overlap, trends toward greater interlevel cooperation have been evident, although they fall considerably short of integrated development.

\section{Comparative Advantages}

During the last quarter of a century, the states have been overshadowed by the federal government in water resources development. The federal government, it is true, does have some inherent advantages in carrying out large-scale improvement programs which cut across state boundaries. However, much of the federal government's superior progress has come through state default, since the states have not effectively exploited their opportunities.

Taken as a group, the states have not maintained a consistent constitutional position with respect to their powers and responsibilities for water resources development, nor have adequate policies been formulated to guide their relationships with the federal government in this field. During times of prosperity, the states have overemphasized states' rights to the point where they have been so concerned with defending their sovereign powers against encroachments by the federal government or other states that they have not given desirable leadership to proposed undertakings. On the other hand, during periods of economic decline, the states have shifted quickly to the other extreme of depending upon the federal government in their solicitations for national aid. Nowhere is this better illustrated than in the State of California, where, during the early days of the depression, state officials pleaded with the federal government to have the Central Valley Project constructed as a

\footnotetext{
${ }^{18}$ Some of the close working relationships between local units and federal agencies are set forth in Charles McKinley, Uncle Sam in the Pacific Northwest (I952).
} 
federal project, and where, since World War II, there has been strong sentiment for state repurchase of federal facilities. ${ }^{10}$

In contrast to state fluctuations, the federal government's role has been expanding, permitting it to step into situations where the states have not had adequate programs. As Congressman Clair Engle has pointed out in connection with the current struggle between various groups in the State of California and the Bureau of Reclamation: ${ }^{20}$

The Bureau of Reclamation has often been criticized for decisions it has made. But often the Bureau of Reclamation has made decisions because there has been no machinery in the State of California and no adequate state law to cover the problems which have arisen.

Until the states adopt a more consistent attitude on the question of states' rights for water resources developments, they will inevitably be at a disadvantage relative to the federal government in this field. Overemphasis upon states' rights rather than states' responsibilities leads to narrow and restrictive programs out of keeping with water needs.

Much has been made of the fact that state boundaries are poorly drawn for effective state participation in water resources development. To be sure, watersheds do not conform to state lines; but by the same token, the federal government is confronted with the necessity of dealing with and through the agencies of several states to operate effectively in a region, so that the argument of state boundary limitations has been much overplayed. The extent to which state boundaries are barriers to effecting wise water resources development will depend upon the legal and administrative arrangements that are worked out between the federal government and the states to deal with problems that cut across state lines. On this score, state weaknesses can be attributed more to poor water resources policies and institutional organization than to inadequate geographical jurisdictions.

The states have also operated under a handicap in this area because the general suspicion exists that the states are not strong enough to protect the public interest. Historically, this suspicion is well-justified, since the states' mismanagement of mineral, forest, and public domain lands constitutes a sordid chapter in American history. Furthermore, a few groups primarily interested in the exploitation of natural resources appear to dominate legislatures and administrative agencies in a number of states, particularly in the West. ${ }^{21}$ Although this domination may not always be unwholesome, it has, nevertheless, led many to view the federal government as the public's best representative for controlling the nation's major water resources.

${ }^{10}$ Sec Hugh G. Hansen, Central Valley Project: Federal or State? (Cal. Assembly Interim Comm. Rep., Vol. 13, No. 6, 1955). It should be noted that since 1954, support for state purchase of the Central Valley Project has declined largely because of the fear that federal support for other needed state water construction projects would be lost.

${ }^{20}$ Irrigation Districts Ass'n of California, Water Policy Problems with Speciat Reference to Federal-State Relationships (I95I).

${ }^{21}$ See, e.g., Morris Garnsey, Ameruca's New Frontuer: The Mountain West (1950); Joseph Kinsey Howard, Montana, High Wide and Handsome (1953). 
The policy-making and administrative agencies of the federal government undeniably draw support from a broader and more varied political base than do state agencies. Moreover, where state political support may be too biased to formulate a balanced water resources program, the federal government can counterbalance undesirable state and intraregional political pressures with pressures from other regions and the nation. On the other hand, neither the legislative nor the executive branches of the federal government have had anything approaching uniform success in integrating political forces into unified water programs, judging by experience in the Missouri, Colorado, or Columbia River basins. More often than not, Congress has abdicated its responsibilities for forming over-all policies, while administrative agencies have worked out some form of Pick-Sloan compromise, so that the final product is often little better than what might have been achieved through interstate negotiation. ${ }^{22}$ The evidence indicates that there needs to be a healthy interplay of federal and state political forces if balanced water resources development is to be achieved.

On the fiscal front, there is no doubt that the federal government's superior financial resources have given it tremendous advantages in determining the course of development in this area. Furthermore, the costs of huge multiple-purpose projects are more feasibly underwritten by the federal government, irrespective of what part it may play in the project's operation. Nevertheless, the fiscal capacity of the states to undertake major programs has not been fully assessed. Although we may be somewhat closer to developing general criteria for determining which costs should be borne by the states and private beneficiaries and which by the federal government, these criteria have not been systematically applied. ${ }^{23}$

To be sure, the states vary in their fiscal capacity, with states such as New York and California in a much better position to undertake projects on their own credit. Most of the states, however, have not effectively addressed themselves to the problem of organizing their fiscal resources and working out financial arrangements with local government units to participate systematically in water resources developments. That much can be done by state and local initiative has been amply demonstrated in Southern California, where state and local agencies have expended over a billion dollars in water development and distribution facilities alone, a figure which becomes more arresting when compared with the approximately six hundred million dollars that the federal government has spent for the entire Central Valley development. ${ }^{24}$ Admittedly, the Southern California achievement is unique, but it, nevertheless, suggests that federal dominance in recent water resources programs is not wholly a consequence of state fiscal inadequacies.

\footnotetext{
${ }^{22}$ A study of congressional failure to deal adequately with Missouri River basin development is to be found in an article by Hart, Legislative Abdication in Regional Development, 13 J. Polimes 393 (1951).

${ }^{23}$ Both the President's Water Resources Policy Commission and the Presidential Advisory Committee on Water Resources Policy have sharpened the principles of cost-sharing, but these have not yet been adopted as congressional policy. See I President's Water Resources Policy Comm'n, op. cit. supra note 4, c. 3; Presidential Advisory Comm. on Water Resources Policy, Water Resources Policy 29-35 (ig55).

21 From figures furnished by the Los Angeles City Department of Water and Power and the Metropolitan Water District of Southern California.
} 
From the standpoint of personnel and administrative organization, both the federal government and the states show some deficiencies in water resources development, although here, again, the states are in the worse position. The federal government is definitely superior in personnel and research facilities. It has developed a far better career service than all but a very few states and over the last half century has built a distinguished professional corps in agencies such as the Geological Survey, the Bureau of Reclamation, and the Corps of Engineers. Moreover, with this personnel have been established research programs and facilities which have given the federal government distinct advantages in gathering data, conducting investigations, and formulating programs. In contrast, the majority of states have been slow to adopt the merit system, have maintained pay scales too low to secure competent men, and have not provided a good working environment for the professional person. As a result, many of the states now rely primarily upon the federal government for information in such fields as topographical mapping or water runoff. Needless to say, under these circumstances, representatives of state agencies have not been in a good bargaining position with their federal counterparts.

A number of other essays in this symposium deal with the inadequacies of federal administrative organization for water resources development. However, it should be noted here that the failure to develop more integrated organization and programs at the federal level has had an unwholesome influence upon state administrative operations. Federal bureaus, such as the Bureau of Reclamation and the Corps of Engineers, have competed for the allegiance of state agencies and local units of government. $^{25}$ Conversely, state governmental units and groups have often used their political power and influence to support the programs of federal agencies. Although there is much that is healthy and inevitable in professional and program liaison between federal and state agencies, interlevel interplay has also been a factor in keeping state administrative organization splintered and has defeated much basinwide planning. ${ }^{26}$

The states have been less able than the federal government to afford the luxury of poor administrative organization for water resources development, since so much of a state's effectiveness in dealing with the federal government and other states hinges upon the unified front which a state can maintain. Over the last decade, a sizable number of the states have underwritten "little Hoover Commission" surveys of state administrative organization, and several have recommended an integration of water resources activities into a single agency or into a broader department of natural resources. ${ }^{27}$ A few states, as, for example, Arkansas and Wyoming, have

${ }^{25}$ Arthur Maass, Muddy Waters: The Army Engineers and the Nation's Rivers (I95I), is an excellent case study of how a federal agency uses its powers and patronage to influence state and local authorities.

${ }^{36}$ For a number of excellent illustrations on this point, see MCKINLEy, op. cit. supra note 18 , and Marian E. Ridgeway, The Missourt Basin's Pick-Sionn Plan (1955).

${ }^{27}$ See Council, of State Governments, State Reorganization in 1950 (1950); The Boor of the STATES, 1952-1953, at 388-89 (1952); id. 1956-r957, at 373-74 (1956). States which have recently established state water resources boards include Kansas, Minnesota, North Carolina, Oregon, Rhode Island, and South Dakota. 
tried to overcome the lack of administrative integration by creating coordinating councils. But on the whole, the organizational progress has not been significant, since states have not appreciated the importance of relating water planning, pollution control, fish protection, or other activities to a program of coordinated management. $^{28}$ Furthermore, multiple-purpose programming has been retarded because the states have not generally promoted drainage-basin planning, even on an intrastate basis. ${ }^{29}$ As a result, major water resources problems within states have been obscured, and many courses of action have been ineffectual.

In summary, there are few fronts upon which the states have maintained parallel status with the federal government in water resources development in recent years. Although there has been a high degree of federal-state administrative cooperation for many water resources activities, the federal government has, more often than not, been the dominant partner. What is important to note, however, is that many of the state shortcomings in this field stem not from lack of adequate powers or facilities, but from a more general weakness of state governments in political, legislative, and executive affairs. ${ }^{30}$ For example, the fact that the states did not see fit to maintain the state-wide planning programs which were inaugurated in the I930's has affected the subsequent course of water resources development. Yet, it is impossible to achieve optimum results under our federal system of government without having wholesome state participation. As the Commission on Intergovernmental Relations has so aptly stated: "The larger the national and international responsibilities of the government in Washington become, the more important it is to have state and local governments to carry out their proper responsibilities." ${ }^{31}$

\section{II}

\section{Federal-State ReLationships}

\section{A. Federal versus State Responsibilities}

What are the proper responsibilities of the federal government vis-à-vis the states for water resources development? Should federal responsibilities be greater for basins which cut across state boundaries than for basins which lie primarily within the confines of one state? Should the economic wealth of a state or a region be a relevant factor in determining the degree of federal versus state action?

\footnotetext{
${ }^{28}$ For the pattern of water resources organization in southern states, see VERA Briscor, JAMEs Wh. Martin, and J. E. Reeves, Safeguarding Kentucky's Natural Resources (1948); LeE S. Greene, Virginia Brown, and Evan W. Iverson, Rescued Earth (r948); Robert B. Hichsaw, Mississippi's Wealth (I947); Christian T. Larsen, South Carolina's Natural Resources (I947); Hunetrt Marshall and Robert J. Young, Public Administration of Florida's Natural Resources (1953); Joseph M. Ray and Lillian Worley, Alabana's Heritage (r947); Paul W. Wager and Donald B. Hayman, Resource Management in North Carolina (1947).

For information on western states, refer to Ostrom, State Administration of Natural Resoltrces in the West, 47 AM. Pol. ScI. Rev. 484 (1953).

${ }^{29}$ Some exceptions are the Miami and Muskingum Conservancy Districts in Ohio, the Willamette River basin studies in Oregon, and the Central Valley developments in California.

${ }^{30}$ Sec Comm'n on Intergovernmental Relations, op. cit. sitpra note 2, at 36-58.

${ }^{31}$ Id. at 57 .
} 
Ever since the nineteenth century, when different reimbursement standards were established for flood control and irrigation, it has been national policy that the obligations of the federal government would not be the same for all phases of water development. Thus, different schedules of state, local, and private repayments now exist for hydroelectric power, reclamation, and other functions. Two criteria which have figured prominently in determining the portion of costs to be borne by the federal government, although not on any scientific basis, have been the probabilities of disaster and the degree to which the benefits are local in character. Recent studies, such as those of the President's Water Resources Policy Commission, have attempted to define more precisely the division of payment between the levels of government for various functions. ${ }^{32}$

Both the federal government and the states, however, bear obligations and responsibilities for water resources development that go beyond specific functions or activities. Certain objectives need to be kept in view in determining what is desirable participation by both levels of government in this area. They may be stated as follows: ${ }^{33}$

First, the federal government bears a responsibility for fostering water resources projects which result in a maximum national economic and social product. The social product is not easily identified, much less measured, but it includes tangible factors, such as the number of kilowatt hours produced by a project, and intangible factors, such as the project's contribution to the welfare of a minority group. It is the task of the political process at the national level to weigh the types of developments in specific locations that will contribute most to the total social product.

Another federal objective in water resources development should be to achieve optimum income distribution. Federal expenditures cannot be justified for projects the benefits of which accrue to a few dominant persons or groups. The concept of minimum income standards is an integral part of the nation's democratic traditions and needs to be observed in these undertakings.

Closely related to the foregoing point is the obligation of the federal government to see that water resources development programs promote and maintain democratic institutions. Decisions involving these programs should be reached with as much public participation as possible. The nation has a stake in formulating water plans which are representative and reflect the public interest.

Finally, the federal government bears a responsibility for aiding states to undertake water resources development programs which will make a distinctive contribution to the national economy and which cannot be underwritten locally. The federal government can assist states in translating national goals into regional programs.

39 I President's Water Resources Policy Comm's, op. cit. supra note 4, at 67-86. See also Presidential Advisory Comar. on Water Resources Policy, op. cit. supta note 23 and House Committee on Public Works, The Allocation of Costs of Federal Water Resources Development Projects, 83d Cong., 2d Sess. (1952).

${ }^{33}$ Some of the discussion for these paragraphs has been adapted from Interregional Linkages, in David Revzan and Ernest T. Engelbert (Eds.), Proceedings of the Western Comamtitee on Regional Economic Analysis 96 (I954). 
Where states or regions are adversely affected by the consequences of developments within other regions, such as was the case when industry migrated from New England to regions in which the federal government had financially supported projects offering hydroelectric power at lower rates, the federal government also has an obligation to assist the disadvantaged areas in making economic readjustments. National policy should be designed to compensate for serious regional dislocations and to promote equilibrium between the competing economies of different basins.

The states, likewise, need to strive for certain objectives in intergovernmental participation in water resources development. If states view their interests within the framework of the national economy, then federal policies should complement state programs. The states, in the long run, stand to benefit from national policies which foster maximum economic product, optimum income distribution, democratic decision-making, and the like. The states, however, need to protect their rights by striving for the following objectives:

First, states should endeavor to receive benefits from water resources development programs proportionate to their contribution. Individual states may well lose their share of rightul gains to other states unless they press their claims. This, of course, does not preclude a state, for reasons of national policy, from receiving benefits from water resources development above and beyond its proportional share at specific stages of its growth. Indeed, in a growing economy it may be expected that there will be some disequilibrium between states and basins; but disproportionate benefits should be explicitly recognized and justified by national policy.

The states should resist water resources development programs which would permit areas outside the basin from draining off local resources without corresponding contributions to the national economy. The states need to be on guard that basins do not become satellites of other regions. Though economic ties will be inevitably stronger between some basins than others, the relationships should be of mutual benefit.

- Equally important is the objective that states should be permitted to organize the economies of basins with as much self-containment as is desired, consonant with the national interest. Economies which are reasonably diversified are more apt to develop the potentialities of states. Moreover, a diversified economy proliferates economic and social groups and provides a stronger political base.

Finally, states should endeavor to have as many political decisions as possible concerning water resources development made locally. Some decisions involving interregional and national issues should be reached at the national level, but if national policies concerning a basin's development are clear, then a greater number of corollary decisions can have local origins. Decentralizing the decision-making process into the state and local areas offers the advantage of broadened popular participation.

Enough of the basic interests of both the federal government and the states in water resources development has been set forth to show that the reconciliation of these objectives into a logical plan calls for balanced and pervasive intergovernmental 
relationships. Undue domination of one level of government by the other not only reduces the possibilities of achieving optimum development, but it weakens the basic structure of federalism. Where there are political or financial obstacles, it may be desirable to have either the federal government or the states take the leadership in getting a project under way, but provision for subsequent joint participation should be made.

\section{B. Effectiveness of Federal-State Relationships}

Over the years, a high degree of cooperation has evolved between various agencies of the federal government and the states in the formulation and administration of water plans. To cite some diverse examples, in the field of research, the Geological Survey has been working with state water agencies in the measurement of surface and ground water supplies, the Bureau of Reclamation with state agricultural experiment stations in the study of irrigation practices, and the Fish and Wildlife Service with state university departments of wildlife management on animal habitat factors. In the field of legislation, many programs call for either joint program formulation or review. Thus, a majority of the states followed the United States Department of Agriculture's model enabling act in establishing state soil conservation districts; the Bureau of Reclamation and the Corps of Engineers are required to furnish proposed projects to the states for consultation and review; and the recently enacted Water Pollution Control $\mathrm{Act}^{34}$ instructs the Public Health Service to work with state agencies in the formulation of pollution-control programs.

Federal-state relationships are perhaps most intermeshed in administrative and operating phases of water resources development programs. Several federal agencies use joint facilities with state agencies and exchange equipment. The Soil Conservation Service furnishes much of the technical services to local conservation districts. The Corps of Engineers often works out a shared program of construction with state and local public works agencies. ${ }^{35}$ Perhaps the most extensive federal-state relationships are those of the Bureau of Reclamation, which, under federal statutes, negotiates water contracts with local districts to build and operate projects for the distribution of water in accordance with state water law, with the facilities being divided between the federal government and local districts when the project is paid for.

Some equally complex federal-state cost-sharing arrangements have been worked out. As examples, states now furnish rights-of-way and obtain land sites for Corps of Engineers projects. Matching grants are extensively employed. Federal loans are available to finance municipal sewage-treatment facilities. Payments in lieu of taxes are made to local units by the United States Department of Agriculture for federal acquisition of land for reservoir sites and project facilities.

\footnotetext{
sk 62 STAT. II55 (1948), 33 U.S.C. $\$ 466$ (1952).

${ }^{36}$ A description of the involved relationships of the Corps of Engineers with state and local governments is to be found in Richard W. Bigger, Flood Control in Metropolitan Los Angeles (unpublished Ph.D. dissertation in University of California at Los Angeles Library I954).
} 
Despite extensive and well-worked-out arrangements between many agencies, however, federal-state relationships have not been conducive to unified water resources planning and development. A review of recent progress in the Missouri, Columbia, Colorado, and Arkansas-White-Red River basins, to mention four of the more prominent, reveals a number of shortcomings. Too much of the planning and programming between federal and state agencies has been unilateral, without sufficient relationship to basin-wide objectives and needs. As the President's Water Policy Commission reported, "... projects are undertaken as if they were ends in themselves, instead of parts of a program designed to meet the needs of the land and of our people."36 Agencies, such as the Corps of Engineers and the Bureau of Reclamation, employ different standards of measurement and feasibility, so that competing programs are offered to the states for bargaining and compromise. ${ }^{37}$ State programs and agencies have often been too weak to get full advantage from cooperating with federal agencies. The Federal Pollution Control Program, for example, is not as successful as it could be, because in many states, adequate regulatory measures have not been enacted. ${ }^{38}$ Perhaps most important of all, the states, independently or collectively, have not sufficiently identified their basic interests and objectives in water resources development so that common goals can be effectively achieved.

Much has been written since World War II about administrative arrangements designed to improve water resources development programs. Although most of the writers will agree that basins are sufficiently different in character to warrant some distinctive administrative framework, proposals for organizational reform fall into three basic categories: (I) those which emphasize more federal leadership; (2) those which emphasize more state leadership; and (3) those which emphasize more shared responsibilities between the federal government and the states. Let us look briefly at federal-state relationships under each of these alternatives.

Advocates of stronger federal leadership support either the establishment of an independent corporation for each basin, along the lines of the Tennessee Valley Authority, or interdepartmental coordinating commissions for each basin with a chairman appointed by the President. ${ }^{39}$ Since the second form of organization has not been instituted, observations concerning federal-state relationships must be limited to the experience of the TVA. Those who have observed the salutary changes that have taken place in state and local government in the seven states within the basin would be inclined to agree that, if anything, TVA has revitalized many

\footnotetext{
${ }^{36}$ I President's Water Resources Policy Comm'N, op. cit. supra note 4, at 43.

${ }^{37}$ A number of these conflicts are set forth in Missouri BAsin SURvey CoMm'N, Missouri: LAND AND WATER 2r5-22 (1953).

${ }^{38} \mathrm{Id}$. at $18 \mathrm{o}$.

${ }^{30}$ For a cogent analysis of the merits of the commission plan, see McKinley, The Valley Authority and Its Alternatives, 44 AM. PoL. Scr. Rev. 607 (1950). The interdepartmental coordinating commission was favored by the President's Water Resources Policy Commission.
} 
state institutions. ${ }^{40}$ Many of the statutory provisions setting forth the Authority's powers have required participation with state and local governments. ${ }^{41}$ The philosophy of Lilienthal, Morgan, Clapp, and others who have shaped the Authority's programs have been anti-big government in viewpoint. ${ }^{42}$ Generally speaking, the governors and representatives in Congress from the TVA region have been the Authority's strongest supporters, which would hardly be the case if the agency were deemed to be undermining the states. ${ }^{43}$ On several counts, therefore, the Authority would appear to receive a clean bill of health with respect to state relationships.

Yet, there is evidence that perhaps federal-state relationships in the Tennessee Valley have not been studied intensively enough, and that, in fact, the states in that region have lost some basic powers over water resources development which they cannot expect to regain short of state recapture of the entire project. A recent study by Elliot Roberts finds that in such basic operations as navigation, power distribution and regulation, and flood control, the TVA exercised exclusive or dominant jurisdiction. ${ }^{44}$ On ancillary issues, such as research or payments in lieu of taxes, Roberts' analysis indicates that the TVA was more willing to seek state aid and participation so long as its control over the basic aspects of river development would not be compromised. Although the author does not decry the TVA dominance, he concludes, in his final chapter, that a "myth of partnership" has been built around federal-state relationships in the Tennessee Valley.

Perhaps the TVA experience demonstrates that it is impossible to divide the basic responsibilities for the control of a river between two levels of government and agencies. Certainly, Roberts' conclusions will give incentive to supporters of state control to improve their arsenal of administrative weapons. To state advocates, a limited number of courses of action are open, depending upon whether the basin is largely within a state or cuts across state lines.

Concerning intrastate basins, the state, with the participation of private enterprise, may either (I) own and operate the facilities; (2) own the facilities and authorize federal operation; or (3) operate the facilities under federal ownership. With the exception of the Central Valley in California, drainage basins lying within the confines of one state are relatively small, and these, in a majority of cases, feed into interstate basins, so that the states are not in a very good position to exercise exclusive jurisdiction on major watersheds. However, a few states have fostered state or private ownership of facilities in some intrastate basins. The Wisconsin Valley Improvement Company, under state regulation, has developed the power facilities for

\footnotetext{
${ }^{10}$ Sec, e.g., Ray, The Influence of the Tennessee Valley Authority on Government in the South, 43 AM. Pol. Scr. Rev. 922 (1949).

"See Durisch, TVA and State and Local Government, in Roscoe C. MArTin (ED.), TVA, THE First Twenty Years c. I5 (I956).

"2 See David E. Lilienthal, TVA: Democracy on the March (1944); see also Gordon R. Clapp, The TVA: AN Approach to the Development of a Region 71-92 (1955).

${ }^{4}$ See Elliot Roberts, One River-Seven States: TVA-State Relations in the Development of THE TenNessee River 2 (I955).

14. at $89-96$.
} 
the entire length of the Wisconsin River. ${ }^{45}$ In Montana, the State Water Conservation Board has developed projects totalling " 26.7 per cent of the total acreage irrigated in the State."46 Although these kinds of examples are few and far between, the evidence suggests that state and local governments could be more resourceful in initiating and conducting basin programs.

With respect to alternative (2), to the author's knowledge, there are no instances of state ownership of basin facilities under federal operation, nor is this alternative being recommended by states' rights advocates. Where a state is financially able to construct projects, little would be gained from the state's viewpoint from placing the management of these projects in federal hands. The states might jointly pledge their resources to develop a project on an interstate stream to be operated by the federal government, but this circumstance appears unlikely.

There is more support for alternative (3)-namely, state operation of federallyowned projects. This method is being currently proposed in California for the Central Valley, where the federal government has a large investment which presently appears too great for that state financially to assume. How much the principle of partnership would gain would depend upon the standards which the federal government sets for the project's operation. One expert who has carefully studied the California proposal concludes that there is little likelihood "that the application of federal laws or controls would be relaxed." ${ }^{\text {"7 }}$ Even so, many persons believe that there are advantages to be derived by the states from state operation of basin projects under federal ownership, despite strict federal standards.

\section{Interstate Compacts}

The more serious problem of federal-state relationships is found in the interstate basin. Here, the interstate compact has been the primary organizational arrangement proposed. Until the enactment of the Colorado River Compact in 1928, the interstate compact, as far as water resources are concerned, had been primarily used to settle boundary disputes. ${ }^{48}$ The Colorado River Compact was hailed as the beginning of a new era in state water development because it was the first compact to deal with the interstate allocation of water resources and because it covered a large basin. Since that time, nearly a score of interstate water compacts have been negotiated, among the most recent significant ones being the Ohio River Valley Sanitation Compact in i948, the Upper Colorado River Basin Compact in 1949, the Connecticut River Compact in 1953, and the Columbia River Commission and the Great Lakes Compacts, the latter two now in the process of ratification. ${ }^{49}$

\footnotetext{
"S See Engel, Wisconsin's Answer to a River Problem, American Forests, Sept. 1950, p. 7.

${ }^{40}$ See R. W. Bowman, Resource Development and the Missouri Rrver Basin io5 (Agricultural Experiment Station, Montana State College Mimeo. Circ. No. 58, x951).

${ }^{\star 7}$ Statement by Norman Sturm, California Division of Water Resources, quoted in HANsEN, op. cit. supra note 19 , at 136 .

${ }^{48}$ See Frederick L. Zimmerman and Mrtcheli. Wendell, The Interstate Compact Since 1925, c. I (195I).

10 For a list of interstate compacts, see Council of State Governments, Interstate Compact8 17831956 (1956).
} 
Proponents have lauded the compacts as an instrument for water resources development on a number of fronts. It is presumed to offer greater opportunity for state initiative and responsibility; it permits local and regional solutions to the immediate problems of an area; it is stated to be a good vehicle for the establishment of joint administrative machinery; it requires both state and federal consent to be operative; and it is an excellent instrument for fostering a healthy federalism. ${ }^{\text {so }}$ Even the most ardent enthusiasts of the compact, however, would admit that in no major basin of the country has the compact succeeded in placing the states on a par with the federal government in water resources development. No administrative agency has yet been evolved out of a compact with sufficient powers and funds to plan for, much less carry out, an integrated basin-wide program.

Critics, in turn, acknowledge that the compact has limited usefulness as an interstate device for resolving legal issues or specific disputes but point out that it is not the machinery for dealing with functions that must be administratively evolved and in which the signatories have competing interests. The commission appointed by the President to make recommendations for administrative organization for the Missouri basin concluded that interstate compacts do not build sufficient regional loyalty and that even a federal-state compact in which the federal government was a more active member "goes too far in the direction of elevating localized state interest over those of the basin and the nation." "51

A reappraisal of the interstate compact leads to the conclusion that, to date, this method has not fostered much integrated water resources development but that it has virtues as an instrument for intergovernmental cooperation. It would appear that we may now be in a position to capitalize on our experience and use compacts as a means of sharing intergovernmental responsibilities and obligations. The chief weakness of compacts has been that they have negotiated agreements too precisely and in too much detail, without sufficient information and study of the problems involved. Moreover, compacts have not provided the proper kind of administrative machinery to deal with the evolving problems of a basin. Some of the newer compacts are endeavoring to deal with these shortcomings. The Upper Colorado River Basin Compact creates an interstate administrative agency and provides for some administrative discretion in dealing with water allocations. ${ }^{52}$ The Sabine River Compact negotiated between Louisiana and Texas in 1956 provides "for a degree of administrative adjudication of water rights by the interstate compact agency." 53 Interstate compacts, however, will never be wholly successful unless they can be effectively tied into existing federal-state arrangements.

\footnotetext{
${ }^{50}$ See Zimmerman and Wendell, op. cit. supta note 48, c. 7; Vincent Thursby, Interstate Cooperation c. 6 (r953); Council of State Governments, The Book of the States, 1950-1951, at 32-33 (1950).

E1 Missouri Basin Survey Comm's, op. cit. supra note 37 , at ro. For a reply to the Commission's statements on the compact method, see Zimmerman and Wendell, Representation of the Region in Missouri Basizs Organization, 48 AM. PoL. Scr. Rev. 152 (I954).

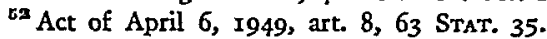

${ }^{83}$ See Council. of State Governments, op. cit. supra note $\mathrm{I}$, at ${ }^{17}$.
} 


\section{Interagency Basin Committees}

A new administrative device which has been developed during the last decade to improve intergovernmental coordination has been the interagency basin committee. Pressures for establishing coordinating committees emanated at both the state and federal levels. During the late r930's, a number of the states became concerned that they needed some sort of interstate organization to counter the dominance of federal programs and to stave off the threat of valley authorities. Federal officials, in turn, feared growing adverse public reaction to the conflicts and competing programs of federal agencies, highlighted during the war by the Bureau of Reclamation-Corps of Engineers controversy in the Missouri basin. In addition, at both levels of government, there was a genuine desire to improve water resources planning and development.

The genesis of the basin committee was in the Missouri basin when, in 1942, the five northern states organized the Missouri Basin States Committee, shortly thereafter expanded to include all ten states of that watershed. ${ }^{54}$ This was followed, in I943, by the creation of a Federal Inter-Agency River Basin Committee (FIARBC) in Washington, D. C., established by informal agreement and composed of the heads of the Bureau of Reclamation, Corps of Engineers, Federal Power Commission, and the Land-Use Coordinator of the Department of Agriculture. ${ }^{5 \sigma}$ Passage of the Flood Control Act of $1944{ }^{56}$ which approved the Pick-Sloan Plan for the development of the Missouri basin, gave further impetus to the establishment, in 1945, of a regional interagency basin committee for the Missouri basin, composed of representatives of parent agencies of the FIARBC and including, by invitation, the governors of the states.

Since that time, interagency basin committees have been organized for four other major regions: the Columbia (1946); the Pacific Southwest (1948); the ArkansasWhite-Red (1950); and New England-New York (1950). The basin committees are similar in that they all have approximately the same federal agency representation. Three, the Columbia, Missouri, and Pacific Southwest Committees, were set up by the parent committee in Washington and are voluntary but continuing bodies; whereas the Arkansas-White-Red and New England-New York Committees were created by presidential directive to prepare "a survey report for submission to the Congress." All have approximately the same federal agency membership, and all but the Pacific Southwest Committee have official state representation. Three of the committees have rotating chairmanships, and all, with the exception of the Missouri Basin Committee, do considerable work through subcommittees. All of

\footnotetext{
${ }^{54}$ See Minutes for Joint Meeting of the Missouri Basin and Arkansas-White-Red Basins Inter-Agency Committees, Vicksburg, Miss., Jan. 31, 1954, p. 2.

${ }^{55}$ Id. at 6 . The Departments of Commerce; Heaith, Education, and Welfare; and Labor subsequently joined the FIARBC.

${ }_{58} 5$ STAT. 887,33 U.S.C. \$7OI (1952).

${ }^{27} 3$ U.S. Comm'n on Organization of the Executive Branch of the Government, Task Fonce Report, on Water Resources and PoWer y 439 (1955).
} 
the basin committees meet several times a year to furnish the membership with information concerning the development of agency programs and to discuss problems of a technical and administrative nature. An examination of the minutes of the committees shows considerable variation in the degree of participation both among federal agencies and state representatives, with meetings that were relatively uneventful and others marked by considerable controversy. None of the committees, however, can take action unless there is unanimous agreement. ${ }^{58}$

What have the interagency basin committees done to improve federal-state relationships in water resources planning? They have served as a means of interdepartmental and interjurisdictional communication and have fostered an awareness of basin-wide problems. ${ }^{59}$ They have facilitated a certain amount of cooperation in research and administrative operation. On occasion, the basin committees have been able to solve minor issues which unattended would have led to friction between agency personnel.

The interagency basin committees, however, have not become integrated intergovernmental planning bodies. In the Arkansas-White-Red basin, where the Committee was most closely knit and where the pressures for coordination from Washington were greatest, the Committee could not reach agreement on one basic plan for stream development. The experience in that region demonstrated that federal agencies in particular were opposed to any basin plans which did not conform to the policies of their respective agencies. ${ }^{60}$ Parallel situations existing in the other basins led the Hoover Commission Task Force to conclude that coordination would continue to fail until there were stronger congressional directives, more consistent policies, and a review board "which is by law superior to the agencies."61

The states, on the whole, have not exercised a very influential role in those basins where they are participating on the committee. Their interests in specific problems have varied, depending upon their geographical location in the basin. ${ }^{62}$ They have been reluctant to become involved in federal agency controversies and have preferred dealing unilaterally with federal agencies. Moreover, being sovereign units, the states have not felt fully committed to basin committee agreements. ${ }^{63}$

Nevertheless, despite the inadequacies of interagency basin committees, recent presidential commission studies, including the Hoover Commission Task Force on Water Resources and Power and the Presidential Advisory Committee on Water Resources Policy, have recommended the continuation and strengthening of these bodies. It has been generally recognized that interagency basin committees do

${ }^{28}$ Id. at $\mathrm{I} 44 \mathrm{I}$.

${ }^{20}$ See, e.g., Columbia Basin Inter-Agency Committee, Plan for Development of Natural Resources of the PACific Northwest (I952).

${ }^{\circ}$ See Irving K. Fox and Isabel Picken, The Upstrean-Downstream Flood Control Controversy in the Arkansas-White-Red Basins Survey (to be published).

61 I Conmin on Organization of the Executive Branch of the Government, op, cit. supta note 57 , at 74 (1955).

-2 See Fox and Picken, op. cit. supra note 6o, at I13.

${ }^{03}$ See Rldgeway, op. cit. supra note 26 , at $3 \mathrm{r} 2$. 
provide a much-needed mechanism for federal-state cooperation in regional water developments. Their future success, however, will depend upon other changes in state and federal policies which need to take place before a good working environment is achieved.

\section{III}

\section{StRengthening the Role of the States}

Since 1950, five federally-created commissions have studied various aspects of federal-state relationships in water resources development-namely, the President's Water Resources Policy Commission (1950), the Missouri Basin Survey Commission (1953), the Commission on Organization of the Executive Branch of the Government (1955), the Commission on Intergovernmental Relations (1955), and the Presidential Advisory Committee on Water Resources Policy (1955). In addition, there has been state sponsorship of studies by the Council of State Governments. ${ }^{0.4}$ Although the investigations of these bodies vary widely in purpose and philosophy, a number of conclusions can be drawn concerning desirable trends.

Without exception, all of the above-named commissions recommended that the role of the states in water resources development should be strengthened. As the President's Water Resources Policy Commission stated, the states perform functions which "are indispensable to full development of water resources and realization of benefits from them." ${ }^{\text {"55 }}$ It was generally recognized that a river may come under both federal and state jurisdiction during the course of its flow and be subject to various types of appropriation, all of which calls for programs involving a high degree of coordinated planning and operation. Both the Commission on Intergovernmental Relations and the Presidential Advisory Committee placed a high premium on maintaining a vigorous federal system, the latter Committee commenting that ${ }^{86}$

complete Federal assumption of responsibility [for the development of the nation's water resources] . . . would destroy the effectiveness of the government of the States and ... work a profound and undesirable change in our traditional plan of government.

The Commission on Organization of the Executive Branch of the Government, perhaps the most outspoken on the states' rights issue, flatly recommended that whenever possible water resources developments "should be discharged by state or local governments ... or by private enterprise."

The commissions were also in general agreement that federal-state water resources

os At the request of the Missouri Basin States Committee, the Council of State Governments, in 1952, drafted a somewhat unique federal-interstate compact for the Missouri basin. The Council has assisted a number of other states in the negotiation of interstate compacts and has often been the spokesman for the state position.

${ }^{o s}$ I President's Water Resources Policy Comm'n, op. cit. supra note 4, at 49.

${ }^{60}$ Presidential Advisory Comm. on Water Resources Policy, op. cit. supra note 23, at 2-3.

or I U.S. Comm'n on the Organization of the Executive Branch of the Government, op. cit. supra note 57 , at 36 . 
relationships should be organized and coordinated around the river basin. Indeed, this was the major theme of both the President's Water Resources Policy Commission and the Missouri Basin Survey Commission reports. Both commissions found that federal and state agencies pursued a functional approach to water resources development that thwarted good intergovernmental relationships in basin development, and both maintained that our system of federalism would be strengthened by the adoption of the basin concept. The Presidential Advisory Committee, however, warned that though basin development of water resources was generally sound, "in some instances consideration of water resources development should be viewed from the standpoint of a region rather than solely from that of a river basin." ${ }^{36}$

The other major area in which the findings of the federal commissions were in substantial agreement concerned the adverse impact that competing federal policies and administrative organization have had upon effective state participation. The Presidential Advisory Committee stated that "the fact that the Federal interest in water resources development has been expressed in different laws empowering differing agencies to pursue particular programs for particular purposes" is the greatest single weakness in the lack of administrative coordination between the federal government and the states. ${ }^{69}$ All of the commissions recommended that the federal government needed to strengthen its own administrative household in order to work effectively with the states.

Beyond these general areas of agreement, the commissions, primarily federallyoriented, varied widely in specific proposals for strengthening the position of the states in water resources development. The only commission specifically charged with studying the role of the states was the Commission on Intergovernmental Relations, and in the water field, its analysis was not too extended. There has been no recent governmental or quasi-public study which has examined the whole field of water policy from the standpoint of the states. Were an objective study undertaken, it is likely that the following courses of action would be proposed:

\section{A. Administrative Reorganization}

A majority of the states desperately need to overhaul their administrative structure for water resources development if they expect to keep pace with federal programs. The State of California, for example, with all of its tremendous water developments, hobbled along until recently with administration of natural resources sprawled over four major departments, ten independent agencies, and forty boards and commissions. ${ }^{70}$ With this kind of divided organization, it is impossible to achieve an integrated state water program. Good reorganization does not necessarily mean that all state water agencies need to be consolidated into one department. It does require, however, an administrative structure that will give coherence to state policies

al Presidential Advisory Comm. on Water Resources Policy, op. cit. supra note 23, at 3-4.

Id. at 2.

${ }^{70} \mathrm{~A}$ new Department of Water Resources was created in 1956, although the reorganization of water agencies is not yet fully accomplished. 
and programs and which will foster coordination around watershed and drainage basins.

Moreover, reorganization of state water agencies must be related to other natural resources functions. Good state programs for drainage basins cannot be developed unless land planning, forestry, recreational, and wildlife activities are intermeshed. The establishment of natural resources coordinating boards at the state level, such as the President's Water Resources Policy Commission has suggested, is not enough unless the boards have legislative and executive powers to formulate and review programs. ${ }^{71}$ Experience has shown that agencies with vested program interests and strong clientele support are not easily persuaded by an advisory body to change their basic policies. Shifting the pattern of state resources operations from a functional to a drainage-basin approach needs approval of both legislative and executive branches. State integration of resources agencies will facilitate better working relationships with the federal government and promote more wholesome political support within the state for balanced resources programs.

\section{B. Policy Formulation and Planning}

The states need to give more attention to the formulation of water resources policies and plans, both on an intrastate and intergovernmental basis. Most of the states do not have an adequate water research or planning staff. Little long-range planning is being done. The states are in a weak position to cooperate with the federal government on this front.

There have been a number of proposals to improve state water planning. One of the more prominent is that states should re-establish state planning commissions charged with the responsibility of the long-range physical developments of the state. If a planning commission is not created, the Presidential Advisory Committee has suggested that a minimum step would be the employment of a moderate staff to participate on a continuing basis "at all stages of water resources planning."72 Such a staff would go a long way toward integrating the research activities of various state agencies and relating them to federal research programs. Another improvement would be the institution of a water resources budget that would reflect both immediate and long-term expenditures and which would present an over-all picture of the state's program. Effective budget preparation fosters public understanding and wise legislative action. Finally, good planning could be fostered by better legislative review of administrative programs. In this connection, it has been suggested that the establishment of a joint committee in the legislature to consider resources programs would result in better policy formulation. ${ }^{73}$

If the states improve planning at the state level, they will then be able to participate more effectively in interstate basin planning. The states should participate in the

$7 x$ I President's Water Resources Policy Comm's, op. cit. supra note 4, at 51 .

${ }^{73}$ Prestdential AdVISORY COMM. ON WATER Resources Policy, op. cit. supra note 23, at 15.

${ }^{73}$ See Laurence L. Durusch and Hershall L. Macon, Upon Its Own Resources 121 (1951). 
initiation of regional programs not simply for the purpose of protecting state interests, but to harmonize state plans with federal and other state developments. Provisions should be inserted in appropriate federal statutes requiring federal agencies to formulate basin-wide programs in conjunction with the states. Future legislation might be patterned after the Water Pollution Control Act of $x 948$ and the Watershed Protection Act of $1954,{ }^{74}$ which provide for a greater degree of federal-state participation in the formulation of programs than has heretofore existed. The Council of State Governments might also be more effectively used as an instrument by the states to promote interstate cooperation in water resources planning.

\section{State Review of Federal Programs}

The states' position in water resources development would be immeasurably strengthened if all federal water resources agencies were required to submit proposed project plans to each of the affected states for official review. The Flood Control Act of 1944 requires the Chief of Engineers and the Secretary of the Interior to follow this procedure, and the Department of Agriculture, by administrative ruling, has now adopted the same practice. ${ }^{75}$ The states are usually given sixty to ninety days to prepare official comments, which are transmitted to Congress attached to the project reports.

All of the recent commissions which have studied the provisions for state review of federal projects have recommended that this requirement be applied to other federal agencies. However, this procedure has not been wholly successful. The time allotted for review has not always given the states adequate time to study the proposals carefully. ${ }^{76}$ Furthermore, neither federal agencies nor Congress have attached sufficient importance to state comments. A remedy would be to adopt the principle set forth in the Watershed Protection Act of 1954 which requires state approval before federal aid can be granted or projects constructed. ${ }^{77}$ But to apply this procedure to all interstate projects would be unwise, since individual states with minor interests at stake could hold up developments indefinitely. A more desirable policy might call for interagency basin committee consideration of state comments with the purpose of reconciling, wherever possible, federal-state conflicts. ${ }^{78}$ Careful examination of the state positions by the United States Bureau of the Budget would also be desirable.

\section{Joint Federal-State Financing}

Previous paragraphs have pointed out that the states have not been sufficiently resourceful in organizing their financial means to participate in large water resources development projects. The position of the states to criticize and propose alternatives to federal projects would be immeasurably strengthened if they assumed a bigger

768 STAT. 666, as amended, I6 U.S.C. \$\$roor-07 (Supp. III, 1956).

${ }^{70}$ See Missouri Basin Survey Comm'n, op. cit. stipra note 37 , at 250.

${ }^{70}$ See Presidential Advisory Comm. on Water Resources Policx, op. cit. supra note 23 , at 14.

${ }^{7 t}$ Sec Comm'n on Intergovernmental Relations, Natural Resources and Conservation 9 (I955).

${ }^{78}$ See Presidential Advisory Comm. on Water Resources Policy, op. cit. supra note 23, at 17. 
share of the financing. Federal agencies, anxious to have no delay or formidable obstacles to their plans, have likewise been at fault for not supporting vigorously the principle of greater state financial participation.

The recent commission studies were unanimous in recommending that the states and local governments and private beneficiaries should bear a greater portion of the cost of water resources development. In general, the commissions favored clearer determinations of national and local benefits, with the states and private beneficiaries assuming costs attributable to the latter. Although official reports have not been too explicit, what specific steps might the states take? First of all, the adoption of better budget planning would provide a better picture of state resources which could be allocated to water resources development. More adequate fiscal planning might also enable the states to work out long-term arrangements for project financing. The states could recapture some of the water project costs by levies upon identifiable beneficiaries. The federal government, in turn, could use matching grants and grants-in-aid with more ingenuity to induce state financial participation. The costs of programs could be worked out jointly by the federal government and the states well in advance of construction schedules and the states obligated to finance their portion of the costs on the basis of pre-agreed time schedules. This would give the states and local governments a longer opportunity to raise revenues and plan for necessary fiscal adjustments.

\section{E. Joint Federal-State Management}

The extent to which the states could construct and operate water resources projects jointly with the federal government or take over the operation and maintenance of projects established by the federal government have not been fully explored. Whether the public welfare would always be served by more state operation is debatable, in view of the special interests of groups in many states that are pressuring for state control of projects now under federal jurisdiction. Yet, this is an issue that will be raised with increasing frequency as the federal government multiplies its efforts in the water resources field and the pressures for decentralization become greater. The Presidential Advisory Committee recommended that "operation of water resources projects be turned over to non-Federal interests as soon as possible in all cases where this is practicable," but it did not spell out the standards that should be maintained in various kinds of projects before federal ownership or responsibilities would be relinquished. ${ }^{7 \theta}$

Obviously, the majority of states do not contemplate operation of large multipurpose development projects, particularly those which are interstate. The states, however, could assume greater responsibility for the operation of smaller developments or manage specific projects in a basin-wide system under basic federal statutes. It would appear that a system of operation such as this may be evolving in California. Legislation with bipartisan support has recently been introduced in both houses of TD $7 d$. at 34 . 
Congress which would authorize the Secretary of the Interior to enter into an agreement wtih the State of California to construct and operate the San Luis unit, a major multiple-purpose project of the Central Valley Project. ${ }^{80}$ Under the bill, the project would be tied into both the federal and state water resources development plans, both units of government would share costs of construction and maintenance, and both would manage portions of the facilities. Although a great number of administrative arrangements would have to be worked out if the plan went into effect, this legislation heralds a new stage in federal-state cooperation.

Both the nation and the states have much to gain from encouraging states to share in the operation of water resources projects with the federal government, even though present federal policies in such fields as irrigation and power distribution prevail. To participate effectively, most of the states would be forced to make some desirable improvements in their administrative structure and operating standards.

State and local financial contributions to projects would probably increase. State operation could foster greater local participation and a better adaptation of operating conditions to local circumstances might result.

\section{F. Intergovernmental Administrative Arrangements}

Increasingly complex water resources developments will call for closer intergovernmental relationships for basin planning. Not only should existing administrative instruments, such as the interstate compact and the interagency basin committee, be improved, but new and varied arrangements should be devised. The interstate compact is a slow and cumbersome process for developing a basin, but it can be a useful means for achieving understanding among units of government. It needs to be employed as an instrument to promote administrative agreement rather than to magnify differences. It is noteworthy that the governors of California and Oregon have recently signed a compact designed to promote the comprehensive development of the Klamath River basin through administrative cooperation, without lengthy litigation. ${ }^{81}$ More consideration should also be given to compacts in which the federal government participates with the states in drafting the provisions.

Despite shortcomings, the interagency basin committees offer a framework for fostering further federal-state cooperation. It is to the states' advantage to have them created for all major basins. The committees should be strengthened both from the standpoint of federal agency coordination and state representation. Following the recommendations of the President's Water Resources Policy Commission, they should be given legislative status, a presidentially appointed chairman, and responsibilities for basin-wide planning. ${ }^{82}$ To bring the states into membership as genuine participants presents some difficult questions of voting rights, particularly if the committees are given formal powers of coordination and clearance; but this can be

${ }^{80}$ S. 1887,85 th Cong., Ist Sess. (1957); H.R. 6035, H.R. 7295, 85th Cong., Ist Sess. (1957).

${ }^{81}$ See Sacramento Bee, April 18, I957, p. E-I. For terms of the compact, see California' Senate Bill 1991 (I957).

80 I Presidenr's Water Resources Policy Comm'n, op. cit. supra note 4, at 49. 
worked out if problems are recognized as having different orders of magnitude for which a single voting formula on all matters is not desirable.

As another possible form of intergovernmental cooperation, consideration should also be given to the possibility of establishing mixed-ownership corporations which would promote and finance improvements, both public and private. The form of the corporation might be patterned along the lines of the Federal Farm Credit and Land Bank organization. The federal government might provide initial working funds but permit state and local governments and accredited private groups to subscribe capital and participate in the management of the corporation through regional or state water resources banks. Projects could be undertaken which might be partially or wholly financed by corporation funds and vary in size from small local improvements to fairly extensive drainage basin programs. Obviously, the establishment of semi-independent corporations raises many implications for state and federal policies and programs. Corporation projects would undoubtedly have to be reviewed to make sure that they did not conflict with established plans for basin development. Nevertheless, this may be a fruitful way of encouraging local initiative as well as facilitating some wholesome decentralization in basin programs.

In conclusion, let it be noted that no basic changes in federal or state powers are necessary to institute the reforms that have been proposed here. Our federal system is adequate, provided that we build wisely upon the existing pattern of intergovernmental relationships. What is sorely needed is public recognition and support for a comprehensive program of water resources development, and legislative and administrative ingenuity in devising the best policies and implementing arrangements for each basin. The information with which to proceed is not lacking. The nation has now had the benefits of a number of major studies and investigations to guide the courses of action. It is high time that both the federal government and the states take steps to carry out the proposals. 